\title{
Women's Role in Household Food Security in Rural Sri Lanka
}

\author{
C.W. Kalansooriya ${ }^{1}$, D.P.S. Chandrakumara ${ }^{2}$ \\ ${ }^{1}$ Lecturer, Department of Economics, University of Sri Jayewardenepura, Sri Lanka \\ ${ }^{2}$ Senior Lecturer, Department of Economics, University of Sri Jayewardenepura, Sri Lanka
}

\begin{abstract}
Food security is a major development issue which has been prioritised in domestic economic policies of many developing countries. Recently, there is an increasing trend of directing food security policies towards empowering women, because, many studies have revealed that women play a significant role in reducing poverty and food insecurity in their households. However, there is a dearth of studies that discusses the women's role in achieving household food security in the context of Sri Lanka, even though women are culturally assigned a huge responsibility in almost all the household tasks including household food management. Hence, this study attempted to analyze the women's role in household food security in Sri Lanka in the rural context. The primary data was gathered from a cross sectional sample survey in Thirappane division in the Anuradhapura district, and the data was collected from 100 households which were selected based on simple random sampling method. To achieve the objectives, both descriptive and econometric methods were used in the data analysis. The study found that women play a strong role in assuring household food security in all three dimensions of food security; they make a significant contribution to farming and thereby household food availability, their contribution to income is crucial in household food access especially in low income households, and their nutritional knowledge is also important inthe proper utilization of food in households. Furthermore, the study estimated a regression model using ordinary least square (OLS) method and could identify that women's income, their nutritional knowledge, and their use of indigenous food management knowledge as important determinants of household food security in rural households. Accordingly, the results suggested that the food security policies in the country should be aimed at empowering women's capacities through income and education to yield better outcomes.
\end{abstract}

Kywords: Food security, Women's role, Rural households 


\section{INTRODUCTION}

Food security, being one of the major issues of the present development dialogue, has been prioritised in domestic economic policies of many developing countries and are also in the agendas of many international organizations especially in the Food and Agriculture Organization (FAO). According to the definition put forward by FAO (1996), food security exists when all people at all times have access to sufficient, safe and nutritious food to maintain a healthy and active life.

Generally, food security has three dimensions; availability, access and utilization, and it can be analyzed in two levels; macro level and micro level. The macro level or national level food security mostly aims at the food availability aspects, while the micro aspects focus on household or individual food acquirement and utilization aspects. Hence, the micro level food security or the household food security depends on many factors such as agricultural production, market availability of food either through national production or imports, income earning opportunities of household members, food aid received to households, intra household decision making, resource allocation and responsibility sharing, care practices in households, and health care given to the household members, etc. In view of all the above factors, household food security can be considered as a multidimensional- multi facet issue which needs an integrated approach to analyze. According to Johnson-Welch et. al. (2000), gender analysis creates the opportunity, and provides a framework for developing such an integrated approach for analyzing household food security.
Gender analysis is important in analyzing household food security due to many reasons. The roles that men and women play regarding food security in their households are usually different; while both men and women are income earners, women play an important role in food security as food producers, processers and preparers, household managers, and food providers for their families. Because of their multiple roles in households, it has been identified that women are key players in overcoming food insecurity at household level. Therefore, strengthening women by enhancing their employment opportunities, assets ownership, credit availability and human capital, is identified as an effective strategy for improving household food security (Quisumbing \& Smith 2007; Roberts 2001; Smith \& Haddad 2000).

In Sri Lanka, the role that women play regarding household food security would not be much different from many other developing countries especially, within the cultural context of Sri Lanka, women are pre-dominantly assigned the role of food preparation and food management within the household. However, there is a dearth of research which comprehensively address this area and proves the relation between women and household food security.

\section{a. The research problem}

Mainstream Economics does not take into account the difference of the economic behavior of men and women. Theories in Economics have been developed on the assumption that there is no difference between men and women in terms of their contribution to production, consumption, resource allocation, decision making, etc. However, 
some researchers have found that females are different from males in the above activities. Emphasizing on the food security in some African and Asian countries, researchers reveal that women play a crucial role in improving the food security at the household level. For example, Quisumbing et al, (1995) showed that women always prioritize household food needs than men do and therefore women's income significantly improve household food consumption and hence children's nutritional status in developing countries. Similarly, Kennedy \& Peter (1992) found that the proportion of income controlled by women has a positive influence on household caloric intake in Kenya and Malawi. Furthermore, many studies show that women's education make a positive impact on agricultural productivity, dietary quality, and children's nutritional status (Ekanayake et al, 2003; Garret \& Ruel, 1999; Gunesekara, 1999; Levin et al, 1999; Olumokaiye \& Ajayi, 2006; Quisumbing, 1996, Varium et al, 1999).

However, a controversy arises with the women's role, especially with women's employment, as several studies reveal the dietary quality of a household is badly affected by women's employments (Haddad \& Hoddinot, 1991; Levin et al 1999; Rao, 2005; Varium et al, 1999). According to them, women's involvement in income earning activities forces them to face a tradeoff between time allocation for employment and household chores. Furthermore, there is a controversy about the food security achievements with the female household headship, as some studies show that household food security is better off with female household headship (Kennedy \& Peter,1992; Levin et al. 1999) while some studies show that it is worse off (Babatunde et al. 2008, Kassie et al. 2012) and some show there is no significant difference in the food security between male headed and female headed households (Malik and Rafi, 2010; Garrett and Ruel, 1999).

In the context of Sri Lanka, it can be identified that the existing literature that reviews food security mostly analyses the macro level (national) food security, and concentrates on analyzing food availability, mostly rice. There are few micro level studies which analyzes household level food consumption, and very few of those have been designed to investigate the women's role. However, those studies concentrate on either calorie consumption measures which interrelated with poverty line definitions (Rathnayake \& Weerahewa, 2003) or on anthropometry measures (Ekanayake et al., 2003; Gunesekara, 1999). On the other hand, those studies had not taken into account the women's role in all three dimensions of food security. Accordingly, this study attempts to solve the problem that whether the women play a significant role in assuring household food security in Sri Lanka in the rural context.

\section{b. Aim and objectives}

The aim of the study is to analyze the women's role in assuring household food security in Sri Lanka in the rural context. In order to achieve this aim the study attempts to fulfill the following specific objectives.

i. To investigate the women's role in each dimensions of food security.

ii. To identify the determinants of household food security with special interest on women's role. 


\section{c. Significance of the study}

Food security is an important development issue frequently addressed by development policies in Sri Lanka. Historically, many food security programs were implemented in the country to overcome food insecurity problems at the household level. However, some of those programs failed in achieving their objectives while some of them yielded successful results. One reason for the failure of some food security programs would be the un-identification of the gender division of responsibilities within the household in assuring food security by the development planners. False assumptions about households as a unit might not produce the expected outcome in case of food security. The identification of gender roles in household food security is very important in policy making as the policies can be directed on most influential groups in reducing food insecurity within households. Therefore, a sound study which analyzes the gender roles in household food security would fill the dearth of research in the field and the result of this study will be beneficial for policy formulations which aim to overcome the food insecurity problem in the country.

\section{MATERIALS AND METHODS}

This study was entirely depended on the primary data which was collected from a sample questionnaire survey. The questionnaire survey was administered in the form of face-toface interviews. To represent the rural population in Sri Lanka, the Anuradhapura district was selected and the sample was selected from the Thirappane division in the Anuradhapura district since $100 \%$ of the population in Thirappane is recorded as rural. The Thirappane division consists of 41 Grama
Niladari (GN) divisions including 82 villages. To cover different kinds of agricultural activities, four Grama Niladari divisions were selected to obtain the sample, namely, Indigahawewa (paddy, chenna, vegetables), Wellamudawa (paddy, corn), Punchikulama (Paddy, vegetables) and Mawathawewa (chilies). Following simple random sampling method 25 households were selected from each GN division totaling to 100 households.. The questionnaire was basically directed to the primary women in each household while a primary woman is defined in this analysis as a female member in the household who most actively participates in the household activities such as food preparation in the household. Accordingly, the primary women were consisted of female household heads, spouses of male headed households, and any other elderly female persons in the households like daughters or grandmothers.

\section{a. Analytical methods}

This study was conducted within the framework of positivist paradigm that uses quantitative analytical techniques. However, it used the nonexperimental observation method to solve the problem. As such, the study used both descriptive and inferential statistical methods in order to achieve the objectives. Descriptive statistical methods were primarily used to identify the socio economic background of the sample and also it used to examine the women's role in three dimensions of food security. Accordingly correlation tests and chi-square tests were used to test the relationships.

A regression analysis was carried out in order to identify the factors affecting household food security with special interest on the factors 
which demonstrate the women's role in a household.

$\mathrm{Z}=\mathrm{f}\left(\mathrm{X}_{1}, \mathrm{X}_{2}, \mathrm{X}_{3}, \ldots \ldots . . \mathrm{X}_{\mathrm{n}} ; \mathrm{Y}_{1}, \mathrm{Y}_{2}, \mathrm{Y}_{3}, \ldots \ldots \ldots \ldots . . . \mathrm{Y}_{\mathrm{n}}\right)$

$Z$ = Level of food security (Household Dietary Diversity Score)

$\mathrm{X}_{1}, \mathrm{X}_{2}, \mathrm{X}_{3}, \ldots \ldots . . \mathrm{X}_{\mathrm{n}}$ : General variables

$\mathrm{Y}_{1}, \mathrm{Y}_{2}, \mathrm{Y}_{3}, \ldots \ldots \ldots \ldots . . . \mathrm{Y}_{\mathrm{n}}$ : Variables demonstrate the women's role

The dependent variable of the regression was the household food security and it was measured using Household Dietary Diversity Score (HDDS). The data for calculating HDDS was obtained through the questionnaire which included questions on food consumption within the recall period of the last 24 hours. There were 12 food groups included in the questionnaire according to the international guidelines of constructing HDDS (Swindale and Bilinski, 2006) with the consideration of local food consumption patterns (Jayawardene et al. 2013). Accordingly, the 12 food categories included in the questionnaire were; cereals, other starchy foods, vegetables, green leaves, fruits, meat, eggs, fish and sea foods, pulses/ legumes and nuts, milk and milk products, oil and fats, and sugar and beverages. The respondents were asked whether they consumed each of those included in the above food groups and assign the value ' 1 ' for positive answers and ' 0 ' otherwise. The respondents were instructed to include the food groups consumed by household members in the home, or prepared in the home and consumed outside the home. As a general rule, food consumed outside the home but was not prepared in the household were not included. The calculation of HDDS was simple. It was the simple sum of the answers of each food group. Since there were 12 food groups, the HDDS varied between 0 and 12 .
The selection procedure of independent variables for the model followed several steps. Initially two sets of explanatory variables, which were assumed as useful in analyzing household food security, were identified based on the conceptual background behind the research problem, on the findings of the existing literature and on the logical thinking of the problem. They consisted of the general variables affecting household food security (X's) and the variables which demonstrated the women's role (Y's). However, it was not possible to include all the identified variables into the final model as some variables showed weaker correlations with the dependent variable and higher correlations between independent variables leading to a multicollinearity problem. Hence, after a careful consideration of the correlations, only few variables were selected as independent variables in the final model. Accordingly, 'family size', 'household total income', 'female contribution to household income', 'education level of the primary women', 'household level food crop growing', 'intention of preparing nutritious food within the household' and 'the use of indigenous knowledge for household management' were the variables included into the final model as explanatory variables.

It is also important to mention how the variables that demontrated the women's role were constructed. The variable 'female contribution to household income' was taken as the proportion of household income earned by the female members in a household. Since the discriptive analysis proved some pattern of the HDDS, according to the percentage of female income contribution, it was decided to categorize the female income contribution into two, as 'above $50 \%$ of contribution' and $50 \%$ or below. Accordingly, two dummy variables were 
incorperated into the model to demonstrate the female income contribution.

Education is generally used in models as a categorical variable. This study divided education into two categories viz., 'up to $\mathrm{O} / \mathrm{L}^{\text {', }}$ and 'A/L and above'. Hence, two dummy variables were used to identify the impact of the education level of the primary women. 'Household level food crop growing' was another variable, which was used to measure the women's role since the data showed more than $75 \%$ of the responsibility of household level food crop cultivations were held by women in the households. The respondents were asked whether they cultivated food crops for home consumption and value '1' was assigned when the answer was 'yes', while it was ' 0 ' otherwise. Accordingly, the observed data in this regard was incorperated in the model as a dichotomous dummy variable.

The variable 'intention of preparing nutritious food within the household' was also a dummy variable that was constructed by considering the respondents' anwers for two questions in the questionnaire. One was whether he/she had a concern on food preparation methods that saved the nutritional quality of food (e.g. boiling, heating or frying). Second, whether he/she normally tried to prepare a balanced diet for each meal. By considering the answers for both questions, households were categorized into two, as households which had no intention of preparing nutritious food and households which had such an intention.

The use of indigenous knowledge for household management' was another variable which demonstrated the women's role. The indigenous knowledge comprised of some food preservation and food management methods which were learnt from older generations. Usually, women transfer the indigenous knowledge and traditional practices from generation to generation and help maintain a smooth consumption of food in the household. Therefore, the respondents were asked whether they used such methods when they manage household food consumption and value ' 1 ' was assigned for positive answers while ' 0 ' for otherwise. Thus, it was included in the model as a dichotomuos dummy variable.

By incorporating the above variables the regression equation was estimated by using the OLS method and it was tested for the violations of OLS assumptions.

\section{RESULTS AND DISCUSSION}

\section{a. Level of food security}

The mean HDDS was recorded as 6.89 in the sample. The minimum number of food categories consumed by the rural dwellers was two, while the highest score was 12 . The highest percentage of households consumed at least 7 food categories in a day.

\section{b. Women's role in household food availability}

Involving in agricultural activities is an important factor of household food availability in rural households. Accordingly, $74 \%$ of households were recorded as engaged in some kind of agricultural activity either in the form of income oriented farming or consumption oriented farming. Considering the gender of the person who is responsible for agricultural activities, the data recorded that out of all farmers in the rural households who earned an 
agricultural income, $74 \%$ were males while $26 \%$ were females.

However, the female involvement in agriculture cannot be estimated by only considering whether they were farmers or not. Even though, they were not recorded as farmers, they contributed to farming through their labour in many ways of the farming activities. Out of all households with agricultural activities, $88 \%$ of households were recorded as they had employed family female labour for their agricultural activities which ranged from planting to selling the crop. The study categorised the female contribution of agricultural activities from the lowest contribution to the full contribution. It was found that women had contributed more than $75 \%$ of the total labour required for farming in the majority of farming activities.

However, the important point noted in the study was that females were not considered as farmers even though they were almost totally responsible for a majority of the farming activities. Therefore, the study attempted to identify why females were not considered as farmers and found that the basic reason was the ownership of land. The title of the farming activities was based on the ownership of land and majority of rural land was owned by males. Respectively, 86 and 87 percent of household heads who owned dry lands and wet lands were males. Based on the ownership of land, females might not be considered as farmers even though they contributed to the entire agricultural process.

Other than food crop growing, another important aspect of food availability at household level is whether that household keeps food stocks (store) within the household at all the time for consumption. Maintaining food stocks is very important in the rural context since the proximity to market is not facilitated and would be difficult and costly to purchase food on a daily basis. According to the findings, woman was the key responsible person in the household with regard to making food available in the household to avoid sudden shortages. The data revealed that maintaining food stocks in the household is positively related with women's income and education, implying that more educated women as well as women who earned more income tend to pay higher attention on maintaining food stocks in the household.

Moreover, the data showed that the use of indigenous knowledge for household food management positively affected the household food security. In the sample, majority of the women were recorded as they apply some kind of food preserving method in their households to keep food available when food is scarce. Drying vegetables, jackfruit, manioc and inland fish, preparing pickles and storing underground were some of those food preservation methods that they had applied.

\section{c. Women's role in household food access}

Household income is the major determinant of food access of a household. The data suggested a strong positive correlation between household total income and the HDDS score. Considering the female contribution to household income, $40 \%$ of households in the sample were recorded as having some kind of female income. The proportion of female income in the household showed a positive relationship with the HDDS in general, although an interesting pattern could be observed from the data for different female income shares. At lower levels of female 
income shares (female contribution for household income was less than 50\%), households recorded a higher level of HDDS, but at higher level of female income shares (female contribution to household income was more than 50\%) the recorded HDDS level was relatively low.

The above pattern can be explained in two ways. Firstly, through the relationship between the female share of the income and the total income of the households. It is important to notice that the recorded correlation between the total household income and the female share of the income was negative, implying that the female share of income is high for low income households. Accordingly, the relationship between the female share of the household income and household food security can be interpreted as, when a household has a higher female income share, the household tends to be poor, and therefore, a higher percentage of those households recorded lower level of HDDS. The second way of interpreting the relationship is the assigned work load for a woman in a household. A woman, who is holding a higher share of household income means that she may have to work longer hours in a day and has to reduce the time allocated for household chores like food preparing. As a result, she would be unable to produce a diverse diet for the household members.

Even though the descriptive analysis showed a lower level of HDDS with higher female contribution, the regression estimates showed that the impact generated from female share on HDDS was higher when female contribution for household income is higher. Such a situation can arise due to the higher dependency of households on female income as a result of the higher female contribution to household income.

Apart from the direct impact made from the female income, it indirectly affects the household food access by improving the ability to maintain a smooth consumption in the household by avoiding sudden food shortages. Households' ability to maintain a smooth consumption was measured by asking a question from households on how they managed the food consumtion when they received an income on a monthly basis or with certain gaps. The answers to this question helped identify four types of households such as 'households which maintained a balanced consumption, households which maintained a balanced consumption with minor difficulties, households where consumption lowered at the tail-end of the income period, and households which depended on debt for consumption. Accordingly, a significant positive relationship could be observed between the ability to smoothing the consumption and the female share of income (Spearman correlation $=0.402$, $\mathrm{p}$ value $=0.000$ ) implying that higher the female share of income, higher is the ability to smooth the consumption. For example, $76 \%$ of households, which recorded as high female income share, were able to maintain a balanced consumption throughout the income interval while only $34 \%$ were able to maintain a balanced consumption within the households which had no female income. Furthermore, the study found that households have a higher ability to maintain a smooth consumption, which leads to a higher possibility of being food secured, when the households' income was managed by women (Chi square value $=22.72$, $\mathrm{df}=3, \mathrm{p}$ value $=0.000)$. For example, out of the households where females managed the expenditure, $56 \%$ recorded a balanced food 
consumption, while it was only $31 \%$ for the male-managed households Furthermore, $16 \%$ of male-managed households recorded as relying on debt compared to $3 \%$ of female managed households.

\section{d. Women's role in household food utilization}

Since the ultimate use of food depends on the preparation of food, the utilization dimension of food security is directly linked with women's role in the households. Women were the main food preparers in the majority of households as nearly $80 \%$ of households recorded as women prepare the household meals. The study found that the women's education and their intention of preparing a nutritious diet, positively correlated with the diversity of the diet consumed by the household members. The recorded HDDS of households was higher with the higher education of the primary women and with the higher intention of preparing a nutritious meal.

The intention of preparing nutritious meal in housheolds was quite low and only $27 \%$ of households paid attention to it while $26 \%$ of households recorded that they had no concern for it at all. It was assumed that the households' intention on preparing a nutritious food was associated with the education levels of the primary woman. Likewise, the results showed a significant positive relationship between the intention of preparing nutritious food and the education level of the primary women (Spearman correlation $=0.416, \mathrm{P}$ value $=0.000$ ). For example, $75 \%$ of primary women who had no education recorded a low concern on the preparation of nutritious food while $71 \%$ of primary women who were university graduates had a higher interest on preparing nutritious food. Women's education has specially affected the nutritional quality of the diet prepared in the household. The households, where the women were more educated, consumed more fruits, more fish and more milk and milk products compared to the households with less educated primary women.

The study also revealed that women paid a higher attention on preparing food within the households rather than consuming food prepared outside. Only 16\% of households were recorded consuming food prepared outsidue where they admitted tooccasionally eating takeaway food as their main meal. An attempt was made to analyse the tendency of eating food from outside the home when women are employed. However, the data did not suggest such a relationship.

\section{e. Determinants of household food security}

According to the regression results in Table 1, the Household Dietary Diversity Score which was determined autonomously from the model was approximately 3 points. The 'size of the family' positively affected, as 0.29 points increase in the HDDS with the increase in one additional member in the family. That means households can gain a higher diversity of the diet when there are more family members in the household.

Total household income showed a significant positive impact on household dietary diversity, in such a way that a 1,000 rupee increase in household income results in a 0.216 point increase in the HDDS. The direction of the impact is agreeable since income is a basic requirement for household food access. Higher income households can acquire more food to fulfill their consumption needs, resulting in a 
consumption of more varied diets compared to low income households. However, the intensity of the impact is contencious, as the HDDS is only slightly improved by the increasing income of a household. By nature, the income elastisity for food items is very low, especially for staples. But the question is whether it is applicable for the variation of the diet as well. Do people not tend to consume a variety of foods which provide different nutritions with the increase in income? According to the findings of this study rural dwellers do not significantly change the consumption pattern or do not variate the diet in response to a change in income. This may rather be so because their diets are hevily dependant on the staples which are grown by themselves.

The female share of income of a household has made differential impacts on household dietary diversity depending on the size of the contribution. The female income contribution has not made any impact on the HDDS of households in which females contributed to less than $50 \%$ of the total household income. If they contributed tomore than $50 \%$ of household income, then the HDDS of those households was 0.8 higher compared to those where there was no female income contribution. The result is rational as the consumption of those households with higher female income share is highly dependant on the incomes of females.

The impact of education level of the primary women on the HDDS was quite ambiguous as women's education had not made any significant impact on the HDDS of rural households. Instead of education, the household intention of preparing a nutritios meal makes a higher impact on dietary diversity of a housheold. The HDDS score was 1.134 higher when women had a higher intention on preparing a nutritious meal, compared to the households which did not have such an intention. This intention is crucial for consuming a varied diet in rural housheolds since the rural dwellers' attention on maintaining a diverse diet is very poor even though they have the ability to do so.

\section{TABLE 01}

Results of the OLS estimation (Dependant variable: Household Dietary Diversity Score

\begin{tabular}{|c|c|}
\hline Explanatory variables & Rural \\
\hline (Constant) & $\begin{array}{l}3.011 * * \\
(3.436)\end{array}$ \\
\hline Family Size & $\begin{array}{l}0.286^{*} \\
(2.288)\end{array}$ \\
\hline Household total income & $\begin{array}{l}2.16 \mathrm{E}-04 * * \\
(2.955)\end{array}$ \\
\hline $\begin{array}{l}\text { Female contribution to household } \\
\text { income }\end{array}$ & \\
\hline $\begin{array}{l}50 \%-100 \% \text { female } \\
\text { share of income }\end{array}$ & $\begin{array}{l}0.811 * \\
(2.079)\end{array}$ \\
\hline $\begin{array}{l}\quad 0 \%-50 \% \text { female share of } \\
\text { income }\end{array}$ & $\begin{array}{c}0.799 \\
(1.743)\end{array}$ \\
\hline $\begin{array}{l}\text { Education level of the primary } \\
\text { women } \\
\text { Up to } \mathrm{O} / \mathrm{L}\end{array}$ & $\begin{array}{c}0.625 \\
(1.524)\end{array}$ \\
\hline $\mathrm{A} / \mathrm{L}$ and above & $\begin{array}{c}1.212 \\
(2.327)\end{array}$ \\
\hline $\begin{array}{l}\text { Intention of preparing nutritious } \\
\text { food within the household } \\
\text { (higher }=1 \text {, lower }=0 \text { ) }\end{array}$ & $\begin{array}{l}1.134 * \\
(2.643)\end{array}$ \\
\hline $\begin{array}{l}\text { Use of indigenous knowledge for } \\
\text { household management } \\
(\text { yes }=1, \text { no }=0 \text { ) }\end{array}$ & $\begin{array}{l}0.777 * \\
(2.396)\end{array}$ \\
\hline $\begin{array}{l}\text { Household level food crop growing } \\
\text { (yes }=1, \text { no }=0 \text { ) }\end{array}$ & $\begin{array}{c}0.178 \\
(0.216)\end{array}$ \\
\hline
\end{tabular}

$* *$ Significant at $1 \% *$ Significant at $5 \%$ 
Another interesting result which was derived from the study was that the HDDS increases by 0.77 points when women use the indigenous knowledge on household management, compared to the households where there was no such thing. Surprisingly, the cultivation of food crops at household level had no impact on the dietary diversity of rural households. This would probably be because the rural dwellers' consumption relies much on staples which grow at their household level.

\section{CONCLUSION}

The aim of the study was to acheive two main objectives. In response to the first objective, the study concluded that the role played by women in their households in achieving food security is immense when considering all three dimensions. In terms of the second objective; food availability, the study found that rural households fulfill a majority of their food needs (staples) from their own cultivation, although the home growing food crops did not increase the diversity of the diet consumed. More importantly, a large part of the responsibility of home growing food crops is taken up by women in households. Other than the contribution to the growing of food crops, women's involvement in making food available in the household could be seen from their effort in maintaining food stocks in the household. In a majority of households women were the main responsible persons in keeping food available in households, and it was found that they took the advantage of their indigenous knowledge in doing so.

Similarly, the study suggests that women's contribution in household income is significant for improving food accessibility especially in the low income households. The impact made from the female income share on food security is high with higher female income shares, since the households predominantly depend on female income in such cases. Apart from the direct impact made from the female income, indirectly it affects household food access by improving the ability to maintain a smooth consumption in the household by avoiding sudden food shortages. Furthermore, the study found that households had a higher ability to maintain a smooth consumption which leads to a higher possibility of being food secured, when the households' income was managed by women.

The utilization aspect is the major dimension of food security in which women play a dominant role, since food preparation and distribution within the household is basically done by women in households. The study found that women's interest on preparing a nutritious meal positively affected household food security in general. Furthermore, the consumption of some food groups which contained more essential micronutrients was high with a higher contribution of female income and the higher female education as well. The study also revealed that even though women face time constraints in providing care for household members since they are engaged in many income earning and other productive activities, they pay a higher attention to preparing meals within the household than turning towards takeaway foods.

Regarding the second objective, the study could identify that household size, household total income, women's higher contribution to household income, their intention towards preparing a nutritional meals, and their use of indigenous food management 
knowledge as important determinates of household food security in rural households.

Hence, policy actions, which improve income earning opportunities for women, particularly in the low income households, are important in assuring food security. It would be very important to encourage women for small scale income earning opportunities, in which they can engage within the home or near their homes, rather than providing employments with high income but reducing the attention on household activities. Furthermore, a policy action towards improving nutritional knowledge among rural women is very important, since rural dwellers do not seem to maintain dietary diversity even though they have the ability to do so. It is not done because not much attention is paid for daily food consumption.

\section{REFERENCES}

\section{ALDERMAN, H., HADDAD, L.,} HODDINOTT, J., \& UDRY, C. (1995).

Gender differentials in farm productivity: implications for household efficiency and agricultural policy: International Food Policy Research Institute.

BABATUNDE, R. O., OMOTESHO, O. A., OLORUNSANYA, E. O., \& OWOTOKI, G. M. (2008). Determinants of Vulnerability to Food Insecurity: A Gender-Based Analysis of Farming Households in Nigeria. Indian Journal of Agricultural Economics, 63(1), 116-125.

CARLETTO, C., ZEZZA, A., \& BANERJEE, R. (2013). Towards better measurement of household food security: Harmonizing indicators and the role of household surveys. Global Food Security, 2(1), 30-40. doi: http://dx.doi.org/10.1016/j.gfs.2012.11.006
DCS. ( 2012). Labor force survey, 2011: Final Report. Colombo: Department of Census and Statistics.

DS - Thirappane. (2012). Sampath Pethikada. Thirappane Division

EKANAYAKE, S., WEERAHEWA, J., \& ARIYAWARDANA, A. (2003). Role of Mothers in Alleviating Child Malnutrition:

Evidence from Sri Lanka. from http://www.pepnet.org/fileadmin/medias/pdf/files_events/3r d_dakar/Ishara_Ratnayake.pdf

FAO. ( 1998). Gender and food security: Synthesis report of regional documents: Africa, Asia and Pacific. Rome: Sustainable Development Department, Food and Agriculture Organization of the United Nations.

FAO. (1996). Women and food security: Women the key to food security Focus. Rome: Food and Agriculture organization.

FAO. (1996). Rome declaration on world food security and World Food Summit plan of action. World Food Summit 13 - 17 November 1996. Rome

FAO. (2002). Food security: Concepts and measurements. In Trade and food security: Conceptualizing the linkage, expert consultation. Economic and social development department, FAO. Rome.

FAO. (2011). The state of food and agriculture 2010-2011 Women in Agriculture; Closing the gender gap for development. Rome: FAO.

GARRETT, J. L., \& RUEL, M. T. (1999). Are determinants of rural and urban food security and nutritional status different? Some insights from Mozambique. World Development, Vol. 27(11), PP 1955-1975.

GROSS, R., SCHOENEBERGER, H., PFEIFER, H., \& PREUSS, H. (2000). The four dimensions of food and nutrition 
security: definitions and concepts. SCN News, 20, 20-25.

GUNASEKERA, H. R. (1999). Nutrition status of children in Sri Lanka. Sri Lankan Journal of Population Studies, 12, 57-73.

HADDAD, L. (1992). The Impact of Women's Employment Status on Household Food Security at Different Income Levels in Ghana. Food and Nutrition Bulletin, 14, no. 4, 341-344.

HODDINOTT, J., \& HADDAD, L. (1991). Household Expenditures, Child Anthropometric Status and the Intrahousehold Division of Income: Evidence from the Cote d'Ivoire. Research Program in Development Studies Discussion Paper, 155, 77-96.

HODDINOTT, J., \& YOHANNES, Y. (2002).

Dietary diversity as a food security indicator. Food and Nutrition Technical Assistance, Academy for educational development. Washington DC.

IFAD. Food Security - a conceptual framework. from http://www.ifad.org/hfs/thematic/rural/rural_ 2.htm

IFPRI. (2000). Women ; The key to food security. Washigton D.C: International Food policy Research Institute.

JAYAWARDENE, R., BYRNE, N.M., SOARES, M.J., KATULANDA, P., YADEV, B., \& HILLS, A.P. (2013). High dietary diversity is associated with obesity in Sri Lankan adults: an evaluation of three dietary scores. BMC Public Health 2013, 13:314

JOHNSON-WELCH, C., ALEMU, B., MSAKI, T. P., SENGENDO, M., KIGUTHA, H., \& WOLFF, A. (2000). Improving household food security; institution, Gender and Integrated approaches. . Madison: BASIS.
KABEER, N. (1990). Women, household food security and coping strategies. Paper presented at the Women's Nutrition. ACC/SCN Symposium Report: Nutrition Policy Discussion Paper. ACCUN SubCommittee on Nutrition.

KASIE, M., NDIRITY, S. W., \& SHIFERAW, B. (2012). Determination of food security in Kenya, A Gender perspective. Paper presented at the 86th Annual Conference of the Agricultural Economic society, University of Warwick, UK.

KENNEDY, E. ( 1991). Income Sources of the Rural Poor in Southwestern Kenya. In J. v. B. a. R. Pandya-Lorch (Ed.), Income Sources of Malnourished People in Rural Areas: Microlevel Information and Policy Implications: Working Paper on Commercialization of Agriculture and Nutrition (Vol. No. 5). Washington, DC: International Food Policy Research Institute. KENNEDY, E., \& PETERS, P. (1992). Household food security and child nutrition: The interaction of income and gender of household head. World Development, 20(8), 1077-1085.

KENNEDY, G., BALLARD, T., \& DOP, M. (2011). Guidelines for Measuring. Household and Individual. Dietary Diversity: FAO.

LEVIN, C. E., RUEL, M. T., MORRIS, S. S., MAXWELL, D. G., ARMAR-KLEMESU, M., \& AHIADEKE, C. (1999). Working women in an urban setting: traders, vendors and food security in Accra. World Development, 27(11), 1977-1991.

MALLICK, D., \& RAFI, M. (2010). Are female-headed households more food insecure? Evidence from Bangladesh. World Development, 38(4), 593-605. 
MC CARNEY, R. A. (1991). Household food security and the role of women. Third World Legal Studies, 10, 157-179.

OLUMAKAIYE, M., \& AJAYI, A. (2006). Women's Empowerment for Household Food Security: The Place of Education. Journal of Human Ecology, 19(1), 51-55.

QUISUMBING, A. R. (1996). Male-female differences in agricultural productivity: Methodological issues and empirical evidence. World Development, 24( 10), 1579-1595.

QUISUMBING, A. R., BROWN, L. R., FELDSTEIN, H. S., HADDAD, L., \& PEÑA, C. (1995). Women: The key to food security Food Policy Report. Washington DC: International Food Policy Research Institute.

QUISUMBING, A. R., RUTH, S., \& MEINZEN, D. (2001). Overview: Empowering Women to Achieve Food Security. Washigton D.C: International Food policy Research Institute.

QUISUMBING, A. R., \& SMITH, L. (2007). Food policy for developing countries; The role of government in the Global food systems, Case study No 4-5. Ithaca, Newyork: Cornell University.

RAMACHANDRAN, N. (2008). Underfed, underpaid and overlooked: Women, the key to food security in South Asia, Gatekeeper series 136

RATHNAYAKA, I., \& WEERAHEWA, J. (2003). Intra household allocation of calories among low income households in Sri Lanka; Impact of female source of income, Progress Report of the project titled "Globalization and Distribution in Sri Lanka" Funded by MIMAR,IDRC

RATHNAYAKE, I., \& WEERAHEWA, J. (2002). An assessment of intra-household allocation of food: a case study of the urban poor in Kandy. Sri Lankan Journal of Agricultural Economics, 4, 95-105.

SAMARATHUNGA, P.A. (2011). Multiple facets of food (in)security in Sri Lanka: An input to food policy. In Mittal, S. \& Sethi, D. (eds), Policy option to achieve food security in South Asia. (pp 51 - 76). Foundation books.

SMITH, L. C., \& HADDAD, L. J. (2000a). Explaining child malnutrition in developing countries: A cross-country analysis. Washington DC: IFPRI.

SMITH, L. C., \& HADDAD, L. J. (2000B). Explaining child malnutrition in developing countries: A cross-country analysis (Vol. 60): Intl Food Policy Res Inst.

SMITH, L. C., RAMAKRISHNAN, U., NDIAYE, A., HADDAD, L., \& MARTORELL, R. (2002). The Importance of Women's Status for Child Nutrition in Developing Countries: Research report 3: International Food Policy Research Institute.

SWINDALE, A. \& BILINSKI, P. (2006). Household dietary diversity score (HDDS) for measurement of household food success: Indicator guide, Version 2. Food and Nutrition Technical Assistant Unit, Academy for educational development. Washington $\mathrm{DC}$ 